\title{
Influence of the North Atlantic subpolar gyre circulation on the 4.2 ka BP event
}

\author{
Bassem Jalali $^{1}$, Marie-Alexandrine Sicre ${ }^{1}$, Julien Azuara ${ }^{2}$, Violaine Pellichero ${ }^{1}$, and Nathalie Combourieu-Nebout ${ }^{2}$ \\ ${ }^{1}$ LOCEAN Laboratory, Sorbonne Universités (UPMC, Univ Paris 06)-CNRS-IRD-MNHN, Paris, France \\ ${ }^{2}$ Histoire naturelle de l'Homme Préhistorique (UMR 7194 CNRS), Département Homme et Environnement, \\ Muséum national d'Histoire naturelle, Institut de Paléontologie humaine,Paris, France
}

Correspondence: Bassem Jalali (bassemfss@gmail.com)

Received: 15 November 2018 - Discussion started: 21 November 2018

Accepted: 18 March 2019 - Published: 8 April 2019

\begin{abstract}
The $4.2 \mathrm{kaBP}$ event, spanning from ca 4200 to $3900 \mathrm{cal} \mathrm{BP}$, has been documented in numerous archaeological data and continental archives across the Northern Hemisphere as an abrupt shift to dry and cold climate. However, data on synchronous ocean circulation changes are notably lacking, thus preventing us from getting a full insight into the physical mechanisms responsible for this climate deterioration. Here, we present two high-resolution (5-20 years) sea surface temperature (SST) records from the subpolar gyre and off north Iceland in the vicinity of the polar front obtained from alkenone paleo-thermometry and compare them with proxy data from the western Mediterranean Sea to gain information on regional temperature and precipitation patterns. Our results are evidence of a temperature dipole pattern which, combined with other paleo-oceanographic records of the North Atlantic, suggests a weakening of the subpolar gyre possibly associated with atmospheric blocked regimes.
\end{abstract}

\section{Introduction}

Holocene rapid climate changes (RCCs) are century-long time intervals of enhanced high-latitude cooling and tropical dryness (Mayewski et al., 2004; Wanner et al., 2011). The forcing mechanisms that trigger these RCCs are multiple and in many cases unclear (Wanner et al., 2014). Bond et al. (2001) suggested a relationship between RCCs and the reduction in the North Atlantic deep-water production (NADW) to explain their transmission around the Northern Hemisphere. By examining 50 globally distributed proxy records, Mayewski et al. (2004) concluded that RCCs re- sult from natural external forcing (i.e., solar and volcanic) and interactions with internal variability (ocean-atmosphere dynamics). Wanner et al. (2011) highlighted the absence of a clear periodicity of the RCCs and the lack of spatiotemporal homogeneity of temperature and humidity patterns of these events. They also recognized that the early Holocene RCC known as the $8.2 \mathrm{ka}$ event likely differed from other Holocene RCCs because of anomalously high freshwater forcing and insolation at the final stage of the deglaciation.

The $4.2 \mathrm{ka} \mathrm{BP}$ event, developing from 4200 to $3900 \mathrm{cal} \mathrm{BP}$ (Weiss, 2016), is one of the most widely documented RCCs. Regarded as the second outstanding RCC after the $8.2 \mathrm{ka}$ event in terms of magnitude and duration, it is often regarded as a boundary between the Middle and Late Holocene climate (Magny et al., 2013; Walker et al., 2012). It is notably known for being synchronous with the occurrence of a megadrought in the Levant and the collapse of the Akkadian Empire and the Old Kingdom in Egypt and, further east, of the Old Chinese cultures (Weiss and Bradley, 2001; Liu and Feng, 2012; Stanley et al., 2003). In the last decade, an increasing number of high-resolution proxy records has provided a more comprehensive description of this event (Weiss, 2016). In the Mediterranean region, climate reconstructions have highlighted a drastic reduction in precipitation and extreme climate conditions prevailing during this period, mostly during the winter season (Magny et al., 2013; Fohlmeister et al., 2013; Zanchetta et al., 2016; Cheng et al., 2015; Ruan et al., 2016; Jalali et al., 2016; Finné et al., 2017; Bini et al., 2019, this issue and references therein). According to Weiss (2015), a 30\%-50\% reduction in precipitation delivered by the Mediterranean westerlies during the 
4.2 ka BP event led to extreme dryness in the Middle East and central Asia. The synthesis of Weiss (2016) also pointed out a weakening of major monsoon systems during this period. Evidence for Indian monsoon disruption comes from highresolution speleothem and Lake Rara precipitation records (Berkelhammer et al., 2012; Dixit et al., 2014; Nakamura et al., 2016). Donges et al. (2015) also reported a weakening of east and southwest Asian summer monsoon resulting in pronounced dryness in northeastern China, Inner Mongolia, and Australia. Finally, a drastic decline in precipitation was also observed over North America (Booth et al., 2005; Fisher et al., 2008).

While the expression of the $4.2 \mathrm{ka} \mathrm{BP}$ event is evident in several paleoclimatic records all over the Northern Hemisphere, physical drivers of this climatic period are still not elucidated in part because of missing data from the ocean, the main water and heat reservoir on Earth. Booth et al. (2005) proposed a La Niña-like pattern and warming of the equatorial Atlantic Ocean to explain enhanced dry conditions in North America between 4100 and 4300 cal BP. Liu et al. (2014) suggested a transition from a negative to a positive Pacific North American (PNA)-like pattern as an alternative explanation. Transient simulations obtained from the Community Climate System Model (CCSM) of NCAR showed that while the modeled large-scale spatial pattern of the 4.2 and $8.2 \mathrm{ka}$ events reproduce a pronounced cooling and precipitation reduction over the Northern Hemisphere, operating mechanisms are different (Ning et al., 2019, this issue). According to this study, in the North Atlantic domain, orbital forcing would have caused a weakening of the Atlantic meridional overturning circulation (AMOC) and subsequent cold and dry conditions of the $4.2 \mathrm{ka} \mathrm{BP}$ event, while freshwater release in the Labrador Sea and subsequent AMOC collapse triggered the $8.2 \mathrm{ka}$ event. Apart from taking place under different insolation conditions, these two RCCs experienced notably different solar and volcanic forcing. Indeed, the absence of large volcanic eruptions (under strong solar activity) during the $4.2 \mathrm{ka} \mathrm{BP}$ event contrasts with the intense volcanism of the $8.2 \mathrm{ka}$ event (Kobashi et al., 2017).

In this paper, we present two unprecedented highresolution (5-20 years) sea surface temperature (SST) records obtained from alkenone analyses in two sediment cores recovered off north Iceland in the western Nordic Seas (MD99-2275) and in the subpolar gyre (SPG), south of Iceland (MD95-2015). This study extends the SSTs of the MD99-2275 in part published by Sicre et al. (2008). New pollen data and already published alkenone SSTs (Jalali et al., 2016) from the KSGC-31 core located in the Gulf of Lion (NW Mediterranean) are also used in the discussion. These records are compared with other regional proxy data from the Euro-Mediterranean region to explore the link between the North Atlantic Ocean circulation and the western European climate during this time span where a disruption of early Mediterranean civilizations was observed.

\section{Material and methods}

The MD99-2275 core was retrieved off north Iceland in the western Nordic Seas $\left(66.55^{\circ} \mathrm{N} ; 17.7^{\circ} \mathrm{W} ; 470 \mathrm{~m}\right.$ water depth) in the vicinity of the present-day polar front (Fig. 1, site 2) where the warm and salty North Icelandic Irminger Current (NIIC) meets with the cold and fresher waters of the East Icelandic Current (EIC) (Fig. 1). The age model of the MD992275 core is based on 15 tephra layers and calculated using the Bayesian approach of the OxCal4.2 software (for details, see Fig. 2 and Table DR4 in Jiang et al., 2015). The second core site MD95-2015 (58.76 ${ }^{\circ} \mathrm{N} ; 25.95^{\circ} \mathrm{W} ; 2630 \mathrm{~m}$ water depth) is located south of Iceland on the eastern flank of the Reykjanes Ridge (Fig. 1, site 1). The age model is based on $21{ }^{14} \mathrm{C}$ dates measured in the planktonic foraminifera Globigerina bulloides (Table S1, Fig. S1 in the Supplement; Kissel et al., 2013). Both cores were collected as part of the international IMAGES program (International Marine Past Global Change Study). The third core KSGC-31 $\left(43^{\circ} \mathrm{N}\right.$, $3.29^{\circ} \mathrm{E} ; 60 \mathrm{~m}$ water depth) was recovered from the Gulf of Lion inner-shelf mud belt during the GM02 Carnac cruise in 2002 (Bassetti et al., 2016). The age model of this core is based on $17{ }^{14} \mathrm{C}$ dates measured on bivalve shells (Table S1, Fig. S2). For MD95-2015 and KSGC-31 cores, the age model was calculated using the Bayesian Oxcal4.3 software (Ramsey, 2017) and the MARINE13 calibration data set (Reimer et al., 2013). Reservoir ages were obtained from the Global Marine Reservoir Database by averaging the eight nearest site reservoir ages of each core (http://calib.org/marine/, last access: 1 April 2019), leading to a $\Delta R=73 \pm 69$ years for MD95-2015 and $23 \pm 71$ years for KSGC-31.

Both MD95-2015 and MD99-2275 sediment cores (Fig. 1, sites 1 and 2 respectively) were continuously sampled at a sampling step of $1 \mathrm{~cm}$ for alkenone biomarker analysis. Lipids were extracted from a few grams of freeze-dried sediments following the experimental procedure adapted from Ternois et al. (1997). Alkenones were isolated from the total lipid extract by silica gel chromatography and quantified using a Varian CX 3400 gas chromatograph after the addition of a known amount of $5 \alpha$-cholestane used as an external standard. SSTs were derived from the unsaturation index of $\mathrm{C}_{37}$ alkenones $U_{37}^{k^{\prime}}=\left(\mathrm{C}_{37: 2}\right) /\left(\mathrm{C}_{37: 2}+\mathrm{C}_{37: 3}\right)$ and the calibration of Prahl et al. (1988), $T=\left(\left(U_{37}^{k^{\prime}}-0.039\right) / 0.034\right) . \mathrm{C}_{37: 4}$ was absent in core MD95-2015 and present in minor amounts in some horizons in the MD99-2275. Based on the age models of the two cores, the mean temporal resolution is estimated to 5 years for MD99-2275 and 20 years for MD95-2015. Internal precision for SST estimates is on the order of $0.5^{\circ} \mathrm{C}$.

Pollen for the KSGC-31 core (Fig. 1, site 10) were generated from 25 samples taken in the $4.2 \mathrm{kaBP}$ time to obtain complementary information on vegetation changes in relation to precipitation that took place in the catchment area of the Gulf of Lion. The pollen extraction procedure follows the standard method modified from Faegri and 


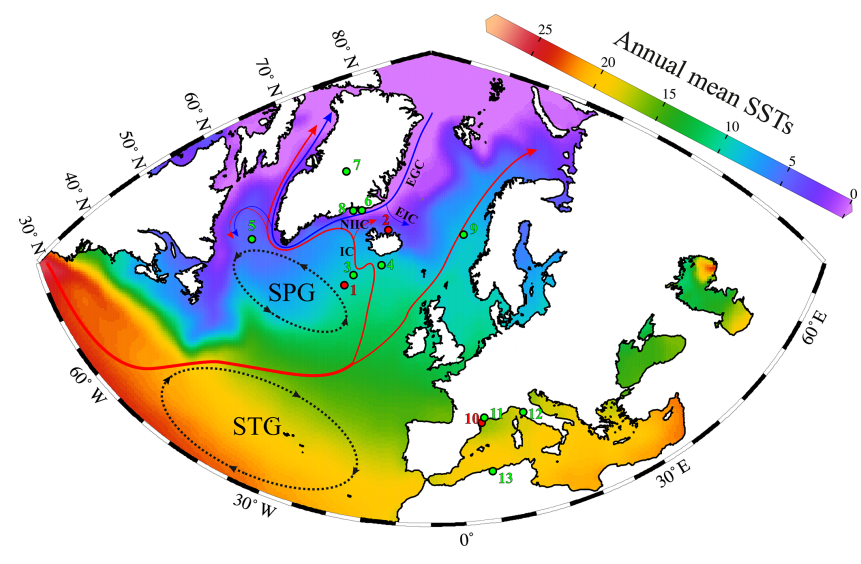

Figure 1. Map of the annual mean SSTs (1955-2012) from the World Ocean Atlas database (https://data.nodc.noaa.gov/las/getUI. do, last access: 1 April 2019; Locarnini et al., 2013) showing the location of the investigated cores and sites used for comparison. (1) Marine core MD95-2015 (this study); (2) marine core MD992275 (this study); (3) marine core GS06-144 08GC (Mjell et al., 2015); (4) marine core RAPiD-12-1K (Thornalley et al., 2009); (5) marine core P-013 (Solignac et al., 2004); (6) marine core JM96 1207 (Solignac et al., 2006); (7) ice core GISP2 (O’Brien et al., 1995); (8) marine core Fox05R/04G (Andresen et al., 2012); (9) marine core MD95-2011 (Berner et al., 2011); (10) marine core KSGC-31 (Jalali et al., 2016); (11) core PB06 from the Palavasian Lagoon (Azuara et al., 2015); (12) speleothem from Renella Cave (Zanchetta et al., 2016); (13) speleothem from Gueldaman Cave (Ruan et al., 2016). Subpolar and subtropical gyres as well as main surface currents in the North Atlantic are also shown. IC: Irminger Current; NIIC: North Icelandic Irminger Current; EIC: East Icelandic Current; EGC: East Greenland Current.

Iversen (1989) (for details see Combourieu-Nebout et al., 1999). Pollen counting was performed on around 300 grains (more than 100 if we except Pinus grains) at $\times 500$ magnification while pollen grains were identified at $\times 1000$ magnification and compared to pollen atlases (Beug, 2004; Reille, 1992). Pollen percentages were calculated after ruling out Pinus pollen because of their overrepresentation in marine sediments (Combourieu-Nebout et al., 1999, 2013 and reference therein). Pollen at this core site originates from a large catchment area, thus providing an integrated picture of the vegetation from the coastline to the top of the nearby mountains. In this study, we use the log of the Fagus / deciduous Quercus ratio to assess precipitation changes. Indeed, it has been shown by Quezel (1979) that Fagus develops mainly in the French Mediterranean mountains, thought at the limit of its geographical range in terms of precipitation requirements (>750 mm). Because deciduous Quercus is more tolerant to dryness than Fagus, decreasing Fagus / deciduous Quercus ratio values presumably reflect increasing aridity (Azuara et al., 2015). The Holocene SST record of the core has been published by Jalali et al. (2016). Based on the age model of the KSGC-31 core, the mean temporal resolution is 15 years for the SST record and 44 years for pollen data.

\section{Results and discussion}

As shown in Fig. 2, the SST signal of the MD99-2275 core contains strong decadal-scale variability with values ranging between 7 and $10^{\circ} \mathrm{C}$ around a mean value of $9^{\circ} \mathrm{C}$. Within the $4.2 \mathrm{ka} \mathrm{BP}$ event interval, shaded in grey, SSTs show an overall cooling of $\sim 2{ }^{\circ} \mathrm{C}$ and a small amplitude temperature reversal around $4200 \mathrm{cal}$ BP followed by an abrupt decline to coldest values $\left(6.7^{\circ} \mathrm{C}\right)$ at $\sim 4100 \mathrm{cal}$ BP. South of Iceland, SSTs fluctuate between 9 and $12^{\circ} \mathrm{C}$ and are thus in a warmer range than off north Iceland as expected from the core locations. They also show marked multi-centennial oscillations of 1 to $2{ }^{\circ} \mathrm{C}$ amplitude but of broadly opposite sign than off north Iceland, with a maximum value of $12^{\circ}$ $\mathrm{C}$ reached around $4100 \mathrm{cal} \mathrm{BP}$. The $\mathrm{C}_{37}$ alkenone concentrations used to derive SSTs in MD95-2015 are on average $334 \mathrm{ng} \mathrm{g}^{-1}$ (range 36 to $700 \mathrm{ng} \mathrm{g}^{-1}$ ) (Fig. 2c). Those found in MD99-2275 range from 20 to $1000 \mathrm{ng} \mathrm{g}^{-1}$, with a mean value of $362 \mathrm{ng} \mathrm{g}^{-1}$ (Fig. 2d). In both cases alkenone abundances were high enough to calculate reliable SSTs.

\subsection{Evidence of weak North Atlantic SPG circulation during the $4.2 \mathrm{kaBP}$ event}

Figure 3 compares our SST data (Fig. 3a, b) and other records from North Atlantic sediments (Fig. 1), which include the proxy reconstruction of the SPG intensity of Thornalley et al. (2009) (Fig. 3c) and the mean grain size of sortable silt (SS; 10-63 $\mu \mathrm{m}$ ) from Gardar drift sediments of Mjell et al. (2015) used as a proxy of the strength of the IcelandScotland Overflow Water (ISOW) (Fig. 3d). Also shown are the Na fluxes from the GISP2 ice core (Fig. 3e) (O'Brien et al., 1995) reflecting changes in atmospheric circulation. Additional information on surface ocean circulation changes is provided by the reconstructions of sea ice concentration over the East Greenland shelf (Fig. 3f) and of the surface salinity in the Labrador Sea (Fig. 3g) (Solignac et al., 2004, 2006). Finally, summer SSTs derived from diatom assemblages (Fig. 3h) were used to assess variations in the warm Atlantic inflow into the Nordic Seas (Berner et al., 2011). These surface water property and proxy reconstructions of dynamical parameters were combined to investigate North Atlantic circulation changes during the $4.2 \mathrm{ka} \mathrm{BP}$ event.

As emphasized in the previous section, warm SSTs in the subpolar gyre region contrast with the cold surface waters in the Nordic Seas during the $4.2 \mathrm{kaBP}$ event (Fig. 3a and b). The same temperature pattern was also evidenced during the Little Ice Age (LIA), the most recent of the Holocene RCCs. Based on model simulations and proxy data, MorenoChamarro et al. (2017) demonstrated that this temperature dipole fingerprints a weakening of the SPG, which in turn created the conditions for atmospheric blocking over the 


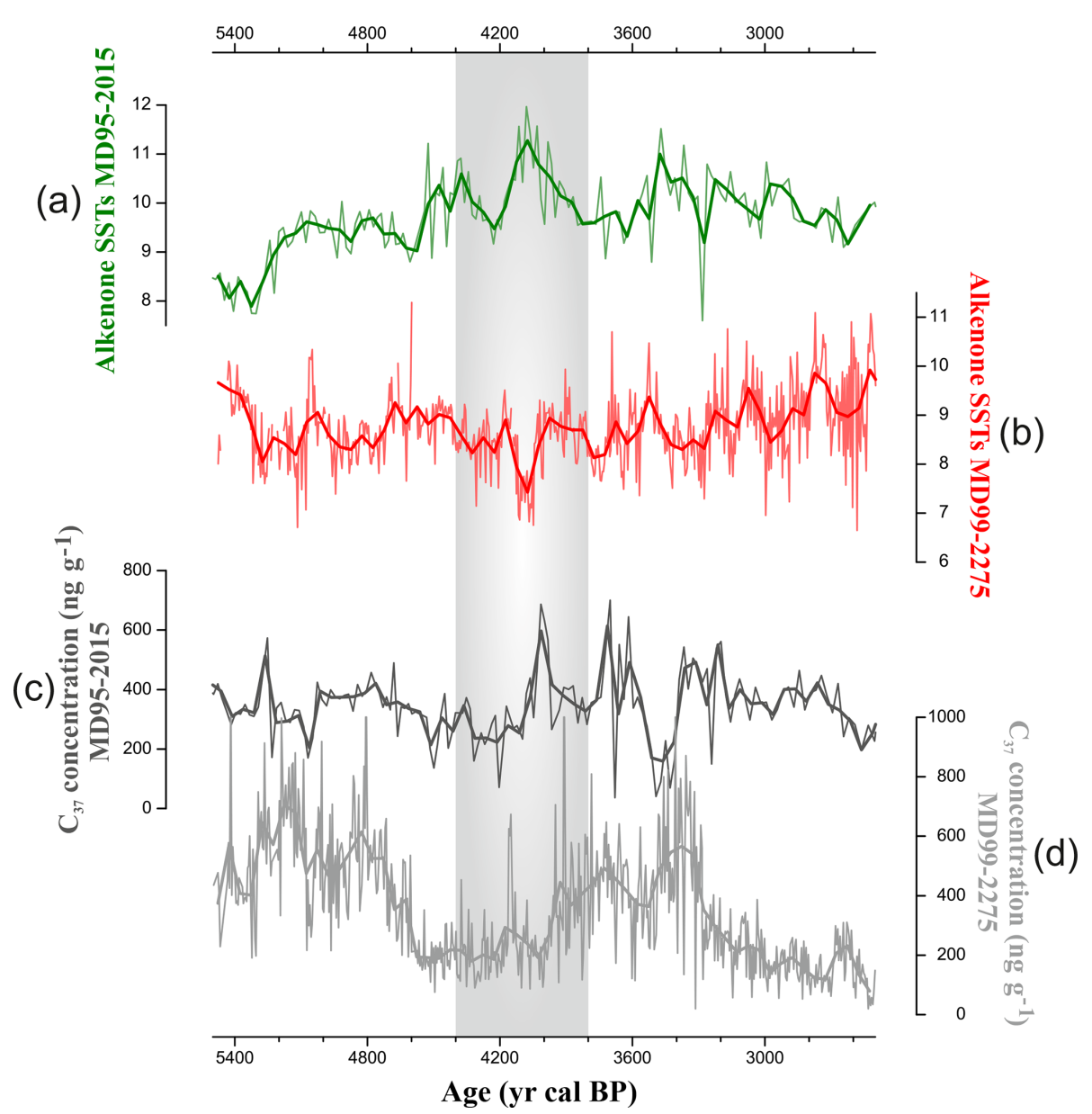

Figure 2. Alkenone-derived sea surface temperatures (SSTs) in the North Atlantic cores between 5500 and 2500 cal BP. (a) At the MD952015 core (site 1 in Fig. 1) and (b) at the MD99-2275 core (site 2 in Fig. 1). (c) $C_{37}$ alkenone concentrations (in ng $g^{-1}$ dry sediment) at the MD95-2015 core and (d) MD99-2275 core. Fifty-year binning is applied to reduce the effect of proxy reconstruction error (thick lines). The grey vertical band represents the $4.2 \mathrm{ka} \mathrm{BP}$ event time interval (4400-3800 cal BP).

northeastern Atlantic (Häkkinen et al., 2011) responsible for severe winters in Europe during the LIA (Luterbacher et al., 2004). Persistent blocking activity has been shown to also trigger rapid ocean changes such as the Great Salinity Anomaly (GSA) in the 1970s. Indeed, blocking over Greenland by enhancing sea ice export from the Arctic Ocean through Fram Strait produces a freshening of the Labrador Sea several years later, the decline in convection and slowdown of the SPG (Ionita et al., 2016). However, the role of external forcing (solar and volcanic) during the LIA remains an open question (Moffa-Sanchez et al., 2014; MorenoChamarro et al., 2016, 2017). Available transient simulations of the $4.2 \mathrm{kaBP}$ event performed with the Community Climate System model version 3 (CCSM3) suggest that internal variability (North Atlantic Oscillation; NAO) could have played an essential role in the SPG circulation change, with possible modulation by external forcings (Yan and Liu, 2019, this issue; Ning et al., 2019, this issue), but none of these simulations have used solar and volcanic forcings. In the fol- lowing, we explore the hypothesis of a reduction in the SPG and causal links between sea ice, wind intensity and AMOC to explain our results.

Figure $3 c$ shows the reconstruction of the SPG strength based on the water density difference between surface and subsurface waters obtained from paired $\mathrm{Mg} / \mathrm{Ca}$ and $\delta^{18} \mathrm{O}$ measurements performed on Globigerina bulloides and Globorotalia inflata, respectively (Thornalley et al., 2009). This density difference reflects the degree of stratification of the upper ocean due to the respective contribution of the North Atlantic Inflow and polar waters. Lower (higher) and decreasing (increasing) values of the water density difference between surface and subsurface layers are indicative of a slowdown (strengthening) of the SPG. This index indicates a gradual decrease in the SPG from 5400 to 4200$4100 \mathrm{cal}$ BP. The parallel decline in the ISOW intensity inferred from the mean SS (sortable silt) suggests a slowdown of AMOC (Fig. 3d) (Mjell et al., 2015) that is supported by cooling of summer SSTs off Norway (Fig. 1, site 9 and 3h; 
(a)

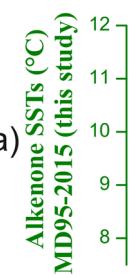

(c)

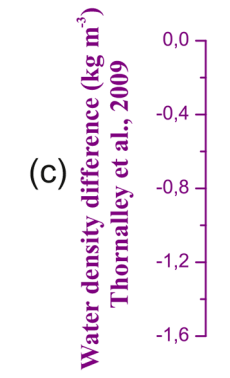

(e)

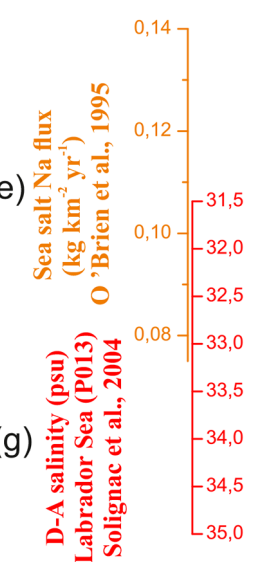

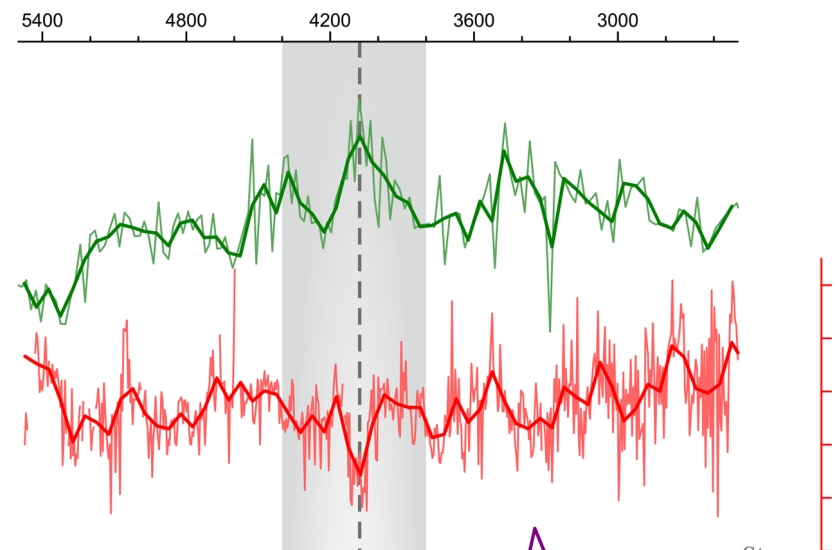

当党离

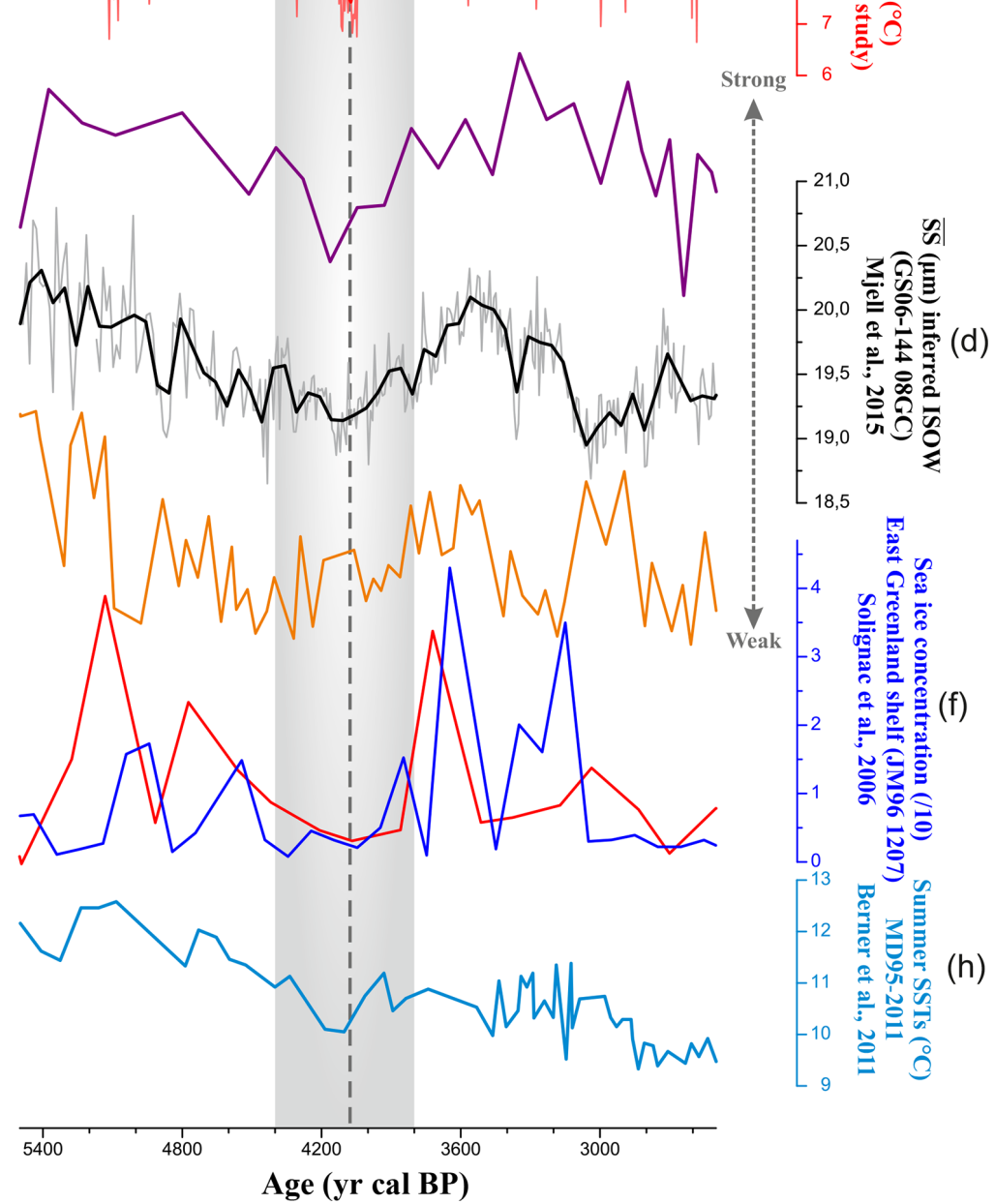

Figure 3. Paleoclimatic and paleo-oceanographic data from the North Atlantic during the $4.2 \mathrm{ka}$ BP event. (a) Alkenone-derived SSTs at the MD95-2015 core. (b) Alkenone-derived SSTs at the MD99-2275 core. (c) Density difference between surface and subsurface waters obtained from paired $\mathrm{Mg} / \mathrm{Ca}$ and $\delta^{18} \mathrm{O}$ in Globigerina bulloides and Globorotalia inflata in core RAPiD-12-1K (site 4 in Fig. 1) (Thornalley et al., 2009). (d) Mean sortable silt (SS, 10-63 $\mu \mathrm{m}$ ) in core GS06-144 08GC in the Iceland Basin (site 3, Fig. 1) (Mjell et al., 2015). (e) Sea salt Na flux from the GISP2 ice core (site 7, Fig. 1) (O'Brien et al., 1995). (f) Sea ice concentration from the East Greenland shelf based on dinoflagellate cyst assemblages in core JM96 1207 (site 6, Fig. 1) (Solignac et al., 2006). (g) Dinoflagellate cyst-assemblage-inferred sea surface salinity from the Labrador Sea core P-013 (site 5, Fig. 1) (Solignac et al., 2004). (h) Summer SSTs derived from diatom-based weighted averaging partial least squares transfer function from core MD95-2011 (site 9, Fig. 1) (Berner et al., 2011). For panels (a), (b) and (d) 50-year binning is applied to reduce the effect of proxy reconstruction error (thick lines). This binning has not been applied to the low temporal-resolution records. The grey vertical band represents the $4.2 \mathrm{ka} \mathrm{BP}$ event time interval (4400-3800 cal BP). The dashed line highlights the $4100 \mathrm{cal} \mathrm{BP}$ where extrema are seen in most records. 
Berner et al., 2011). All together, these reconstructions indicate a progressive slowdown of the SPG and AMOC between 5400 and $4200-4100$ cal BP and consecutive northward ocean heat transport reduction leading to cold conditions in the Nordic Seas.

Freshwater export from the Arctic Ocean and wind stress are important controlling factors of the SPG circulation through deep convection in the Labrador Sea (Langehaug et al., 2012; Born and Stocker, 2014). Increased sea salt Na flux in Greenland ice cores has been related to the expansion of the polar vortex and/or enhanced meridional wind flow. The coeval weakening of the SPG and negative trend of the Na fluxes until approximately 4200-4300 cal BP can be explained either by a decrease in wind intensity or more sea ice both acting to reduce the production of sea salt aerosols (Fig. 3e). Available proxy records of sea ice out of the Arctic Ocean through Fram Strait for this period are scarce. However, the low-resolution time series from south of the Denmark Strait based on dinoflagellate cyst assemblages suggest that the 4500-3900 cal BP interval would have been a longstanding period with almost no sea ice (Fig. 3f; Site 6 in Fig. 1; Solignac et al., 2006). The diminished influence of polar waters is also supported by increasing sea surface salinity in the Labrador Sea between 4800 and 4000 cal BP (Fig. 3g; site 5 in Fig. 1; Solignac et al., 2004). Both proxy reconstructions therefore point to a weak East Greenland Current (EGC) along the East Greenland coast during this time period (Solignac et al., 2006; De Vernal et al., 2013).

Paleo-data as well as modern observations have also shown that in a weak state, the SPG is confined to the western part of the basin and has a north-south orientation favoring the Irminger Current (IC) inflow to the SE GreenlandNW Iceland shelf (Hátún et al., 2005; Andresen et al., 2012). Such incursions of warm IC water have notably been evidenced by high occurrences of the benthic foraminifera Cassidulina neoteretis between 5200 and $4200 \mathrm{cal} \mathrm{BP}$ at the core Fox05R/04G site by Andresen et al. (2012) (site 8 in Fig. 1). A weak SPG induces a surface cooling in the Nordic Seas due to decreased heat transport, thereby promoting the expansion of sea ice cover especially in the Nordic and Barents seas (Moreno-Chamarro et al., 2017). This is in agreement with the long-term cooling of the Nordic Seas reported by Berner et al. (2011) along the Norwegian coast (Fig. 3h) and the increased abundance of sea ice diatoms between 4300 and 4100 cal BP in MD99-2275 that parallels the alkenone SSTs decrease (Ran et al., 2008). Note that Ran et al. (2008) further specified that this increase was marginally due to Arctic sea ice diatoms, which further supports the assumption of a low Arctic water influence. Instead, local sea ice formation would have been favored by colder conditions. Sea ice concentration in the Barents Sea shows consistently increasing values since 4600 cal BP (De Vernal et al., 2013) as opposed to SE Greenland and the Labrador Sea, in agreement with the SST dipole featuring a weak SPG. The $4.2 \mathrm{kaBP}$ event would thus differ from the LIA marked by the return of sea ice and the southeastern expansion of the polar front (Massé et al., 2008; Sha et al., 2016). Although proxy records of the $4.2 \mathrm{kaBP}$ event suggest a reduction in the SPG, ISOW and possibly of the AMOC, the mechanisms involved are likely to be different because of less severe sea ice conditions and feedbacks as well as external forcing. In the next section we discuss the climatic expression of the $4.2 \mathrm{ka} \mathrm{BP}$ event in the Euro-Mediterranean region based on the continental record of concomitant hydroclimate changes.

\subsection{Climatic expression in the Euro-Mediterranean region}

Figure 4 shows high-resolution SST and pollen records from the Gulf of Lion together with the oxygen isotope signals of two stalagmites from the western Mediterranean sensitive to continental precipitation (Zanchetta et al., 2016; Ruan et al., 2016). SSTs in the Gulf of Lion (site 10 in Fig. 1) reveal a $\sim 2{ }^{\circ} \mathrm{C}$ cooling between 4400 and $3800 \mathrm{cal} \mathrm{BP}$, with two brief colder intervals around 4300 and $4100 \mathrm{cal} \mathrm{BP}$ that seem to coincide with the colder SSTs seen off north Iceland. Yet cooling at $4100 \mathrm{cal} \mathrm{BP}$ is sharp and more prominent in the western Nordic Seas, possibly due to the presence of sea ice (Fig. 4a, d). Coldest SST values in the Gulf of Lion during the LIA have been related to persistent wintertime atmospheric blocking over the NE Atlantic resulting in more intense and colder mistral winds, blowing all year round but more strongly during the winter season (Sicre et al., 2016), that are consistent with the previously discussed North Atlantic paleo-data and model simulation results (Moffa-Sanchez et al., 2014; Moreno-Chamarro et al., 2016, 2017). Pollen data were investigated to assess environmental conditions over adjacent continental regions to complement the information provided by SSTs. The Fagus / Quercus ratio values between 4400 and $3800 \mathrm{cal} \mathrm{BP}$ indicate vegetation changes that broadly reflect wetter conditions with a higher representation of Fagus (associated with Abies) in the forest. This is in agreement with the same ratio record from the nearby Holocene Palavas Lagoon sediments (site 11 in Fig. 1; Azuara et al., 2015) (Fig. 4b, c). A short event centered at $4200 \mathrm{cal}$ BP (and possibly around $3900 \mathrm{cal} \mathrm{BP}$ ) showing a decrease of Fagus in favor of Quercus may be indicative of a brief spell of moderate dryness. This change can be related to a lower temperate forest development seen in the central Italy records of Lago di Vico and Lagaccione (Magri and Sadori, 1999; Magri, 1999) and in the Gulf of Gaeta (Di Rita et al., 2018). In central Italy and in the Gulf of Lion, pollen data do not show a significant change in vegetation but only a modification of the forest composition that corresponds to a slight decrease in precipitation (Di Rita and Magri, 2019; this issue). The speleothem data from Italy and Algeria give a more detailed and complex picture of precipitation during the $4.2 \mathrm{ka} \mathrm{BP}$ event. The oxygen isotope records from the Renella Cave stalagmite in Italy (Fig. 4e; Zanchetta et al., 2016; site 12 in Fig. 1) and Gueldaman Cave in northern Algeria (Fig. 4f; Ruan et 


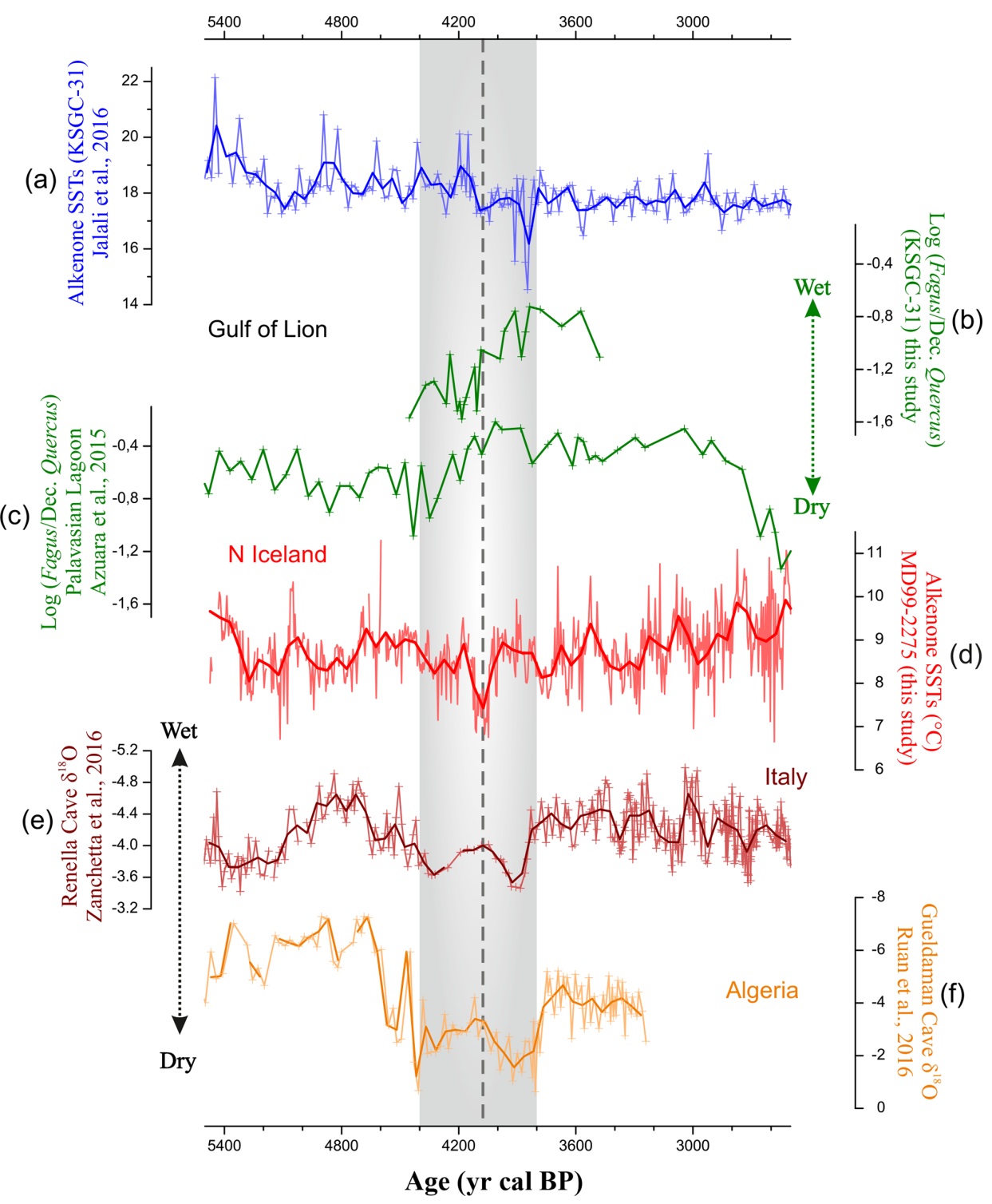

Figure 4. Expression of the $4.2 \mathrm{kaBP}$ event in the W Mediterranean region as recorded by marine and continental archives. (a) Alkenone SSTs at the KSGC-31 core in the Gulf of Lion (site 10, Fig. 1; Jalali et al., 2016). (b) Log Fagus / deciduous Quercus in the KSGC-31 core (this study). (c) Log Fagus / deciduous Quercus in core PB06 from the Palavasian Lagoon (site 11, Fig. 1; Azuara et al., 2015). (d) Alkenone SSTs at the MD99-2275 core (site 2, Fig. 1) (north Iceland; this study). (e) $\delta^{18} \mathrm{O}$ record obtained from Renella Cave stalagmite (site 12 , Fig. 1) (north Italy; Zanchetta et al., 2016). (f) $\delta^{18}$ O record obtained from Gueldaman Cave stalagmite (site 13, Fig. 1) (Algeria; Ruan et al., 2016). A 50-year binning is applied to reduce the effect of proxy reconstruction error (thick lines). The grey vertical band represents the $4.2 \mathrm{ka} \mathrm{BP}$ event time interval (4400-3800 cal BP).

al., 2016; site 13 in Fig. 1) both indicate increasingly drier conditions starting around $4800 \mathrm{cal} \mathrm{BP}$. At Gueldaman Cave, archaeological data indicate the settlement abandonment of the cave by human groups around $4400 \mathrm{cal}$ BP (Ruan et al., 2016). Both sites witness marked aridity conditions between 4400 and $3800 \mathrm{cal}$ BP but a distinct, slightly wetter period between 4200 and 4100 cal BP. The pollen data in the Gulf of Lion seem to depict a similar complex structure of this interval that, however, appears to reflect generally more humid conditions of the catchment basin of the KSGC-31 site. Inter- estingly, the same double-peak centennial-scale cooling and drought have been detected in transient simulations over the past 21000 years, and the dry phases have been attributed to the presence of anticyclones over western Europe (Yan and Liu, 2019; this issue). These model results also indicate a southern shift of the ITCZ that is consistent with a weakening of the AMOC. 


\section{Conclusions}

Unprecedented high-resolution alkenone-derived SST records of the $4.2 \mathrm{kaBP}$ event have been generated from the western Nordic Seas and North Atlantic sediments in order to explore causes for this cold or dry event of the mid-Holocene and the role of the ocean in the observed changes. The spatial distribution of the SST indicates a cold or warm dipole between 4400 and 3800 cal BP that characterizes a weak SPG, which is supported by other marine proxy records across the North Atlantic. Enhanced wintertime North Atlantic anticyclone blocking induced by a weak subpolar gyre circulation would account for cold and drought conditions. Continental proxy records in Italy and Algeria indicate a double-peak centennial-scale structure of the $4.2 \mathrm{kaBP}$ event with prevailing dry conditions interrupted by a slightly wetter period that is also seen in transient model simulations. These numerical experiments suggest a more important role of internal variability and insolation than during the LIA. More investigations are needed to confirm our findings to get a mechanistic understanding of climate during this period.

Data availability. Data presented in the paper can be accessed by contacting the corresponding author. The data will be archived at the National Climate Data Center (https://www.ncdc.noaa.gov/ data-access/paleoclimatology-data, last access: 2 April 2019).

Supplement. The supplement related to this article is available online at: https://doi.org/10.5194/cp-15-701-2019-supplement.

Author contributions. MAS and VP performed the alkenone analysis; NCN and JA performed the pollen analysis; BJ and MAS prepared the paper with contributions from all coauthors.

Competing interests. The authors declare that they have no conflict of interest.

Special issue statement. This article is part of the special issue "The $4.2 \mathrm{ka}$ BP climatic event". It is a result of "The $4.2 \mathrm{ka} \mathrm{BP}$ Event: An International Workshop", Pisa, Italy, 10-12 January 2018.

Acknowledgements. This work was financially supported by the MISTRALS/PaleoMex program. The research leading to this study has received funding from the French National Research Agency HAMOC project (ANR-13-BS06- 0003). We thank Sandrine Canals for the pollen sample processing at ISEM laboratory in Montpellier.
Review statement. This paper was edited by Harvey Weiss and reviewed by Eduardo Moreno-Chamarro and five anonymous referees.

\section{References}

Andresen, C. S., Hansen, M. J., Seidenkrantz, M. S., Jennings, A. E., Knudsen, M. F., Nørgaard-Pedersen, N., Larsen, N. K., Kuijpers A., and Pearce, C.: Mid-to late-Holocene oceanographic variability on the Southeast Greenland shelf, Holocene, 23, 167178, 2012.

Azuara, J., Combourieu-Nebout, N., Lebreton, V., Mazier, F., Müller, S. D., and Dezileau, L.: Late Holocene vegetation changes in relation with climate fluctuations and human activity in Languedoc (southern France), Clim. Past, 11, 1769-1784, https://doi.org/10.5194/cp-11-1769-2015, 2015.

Bassetti, M.-A., Berné, S., Sicre, M.-A., Dennielou, B., Alonso, Y., Buscail, R., Jalali, B., Hebert, B., and Menniti, C.: Holocene hydrological changes in the Rhône River (NW Mediterranean) as recorded in the marine mud belt, Clim. Past, 12, 1539-1553, https://doi.org/10.5194/cp-12-1539-2016, 2016.

Berkelhammer, M., Sinha, A., Stott, L., Cheng, H., Pausata, F. S. R., and Yoshimura, K.: An abrupt shift in the Indian monsoon 4000 years ago, in: Climates, landscapes, and civilizations, edited by: Giosan, L., Fuller, D.-Q., Nicoll, K., Flad, R.-K., and Clift, P.D., American Geophysical Union Geophysical Monograph, 198, 75-87, https://doi.org/10.1029/2012GM001207, 2012.

Berner, K. S., Koç, N., Godtliebsen, F., and Divine, D.: Holocene climate variability of the Norwegian Atlantic Current during high and low solar insolation forcing, Paleoceanography, 26, PA2220, https://doi.org/10.1029/2010PA002002, 2011.

Beug, H. J.: Leitfaden der Pollenbestimmung für Mitteleuropa und angrenzende Gebiete, Verlag Dr. Friedrich Pfeif, München, Germany, 542 pp., 2004.

Bini, M., Zanchetta, G., Persoiu, A., Cartier, R., Català, A., Cacho, I., Dean, J. R., Di Rita, F., Drysdale, R. N., Finnè, M., Isola, I., Jalali, B., Lirer, F., Magri, D., Masi, A., Marks, L., Mercuri, A. M., Peyron, O., Sadori, L., Sicre, M.-A., Welc, F., Zielhofer, C., and Brisset, E.: The 4.2 ka BP Event in the Mediterranean region: an overview, Clim. Past, 15, 555-577, https://doi.org/10.5194/cp-15-555-2019, 2019.

Bond, G., Kromer, B., Beer, J., Muscheler, R., Evans, M. N., Showers, W., and Bonani, G.: Persistent solar influence on North Atlantic climate during the Holocene, Science, 294, 2130-2136, 2001.

Booth, R. K., Jackson, S. T., Forman, S. L., Kutzbach, J. E., Bettis III, E. A., Kreig, J., and Wright, D. K.: A severe centennial-scale drought in mid-continental North America 4200 years ago and apparent global linkage, Holocene, 15, 321-328, 2005.

Born, A. and Stocker, T. F.: Two stable equilibria of the Atlantic subpolar gyre, J. Phys. Oceanogr., 44, 246-264, 2014.

Cheng, H., Sinha, A., Verheyden, S., Nader, F. H., Li, X. L., Zhang, P. Z. J., Yin, J., Yi, L., Peng, Y. B., Rao, Z. G., Ning, Y. F., and Edwards, R. L.: The climate variability in northern Levant over the past 20,000 years, Geophys. Res. Lett., 42,, 8641-8650, 2015.

Combourieu-Nebout, N., Londeix, L., and Baudin, F.: Quaternary marine and continental paleoenvironments in the western Mediterranean (Site 976, Alboran Sea): Palynological evidence, 
in: Proceedings of ODP Scientific Results, edited by: Zahn, R., Comas, M. C., and Klaus, A., Ocean Drilling Program, College Station, TX, USA, 161, 457-468, 1999.

Combourieu-Nebout, N., Peyron, O., Bout-Roumazeilles, V., Goring, S., Dormoy, I., Joannin, S., Sadori, L., Siani, G., and Magny, M.: Holocene vegetation and climate changes in the central Mediterranean inferred from a high-resolution marine pollen record (Adriatic Sea), Clim. Past, 9, 2023-2042, https://doi.org/10.5194/cp-9-2023-2013, 2013.

De Vernal, A., Hillaire-Marcel, C., Rochon, A., Fréchette, B., Henry, M., Solignac, S., and Bonnet, S.: Dinocyst-based reconstructions of sea ice cover concentration during the Holocene in the Arctic Ocean, the northern North Atlantic Ocean and its adjacent seas, Quaternary Sci. Rev., 79, 111-121, 2013.

Di Rita, F. and Magri, D.: The $4.2 \mathrm{ka}$ event in the vegetation record of the central Mediterranean, Clim. Past, 15, 237-251, https://doi.org/10.5194/cp-15-237-2019, 2019.

Di Rita, F., Fletcher, W. J., Aranbarri, J., Margaritelli, G., Lirer, F., and Magri, D.: Holocene forest dynamics in central and western Mediterranean: periodicity, spatio-temporal patterns and climate influence, Sci. Rep.-UK, 8, 8929, https://doi.org/10.1038/s41598-018-27056-2, 2018.

Dixit, Y., Hodell, D. A., and Petrie, C. A.: Abrupt weakening of the summer monsoon in northwest India $\sim 4100 \mathrm{yr}$ ago, Geology, 42, 339-342, 2014.

Donges, J. F., Donner, R. V., Marwan, N., Breitenbach, S. F. M., Rehfeld, K., and Kurths, J.: Non-linear regime shifts in Holocene Asian monsoon variability: potential impacts on cultural change and migratory patterns, Clim. Past, 11, 709-741, https://doi.org/10.5194/cp-11-709-2015, 2015.

Faegri, K. and Iversen, J.: Textbook of pollen analysis, 4th Ed., edited by: Faegri, K., Kaland, P. E., and Krzywinski, K., Wiley, Chichester, UK, 1989.

Finné, M., Holmgren, K., Shen, C. C., Hu, H. M., Boyd, M., and Stocker, S.: Late Bronze Age climate change and the destruction of the Mycenaean Palace of Nestor at Pylos, PloS one, 12, e0189447, https://doi.org/10.1371/journal.pone.0189447, 2017.

Fisher, D., Osterberg, E., Dyke, A., Dahl-Jensen, D., Demuth, M., Zdanowicz, C., Bourgeois, J., Koerner, R. M., Mayewski, P., Wake, C., Kreutz, K., Steig, E., Zheng, J., Yalcin, K., GotoAzuma, K., Luckman, B., and Rupper, S.: The Mt Logan Holocene - late Wisconsinan isotope record: tropical PacificYukon connections, Holocene, 18, 667-677, 2008.

Fohlmeister, J., Vollweiler, N., Spötl, C., and Mangini, A.: COMNISPA II: Update of a mid-European isotope climate record, $11 \mathrm{ka}$ to present, Holocene, 23, 749-754, 2013.

Häkkinen, S., Rhines, P. B., and Worthen, D. L.: Atmospheric blocking and Atlantic multidecadal ocean variability, Science, 334, 655-659, 2011.

Hátún, H., Sand $\varnothing$, A. B., Drange, H., Hansen, B., and Valdimarsson, H.: Influence of the Atlantic subpolar gyre on the thermohaline circulation, Science, 309, 1841-1844, 2005.

Ionita, M., Scholz, P., Lohmann, G., Dima, M., and Prange, M.: Linkages between atmospheric blocking, sea ice export through Fram Strait and the Atlantic Meridional Overturning Circulation, Nat. Sci. Rep., 6, 32881, https://doi.org/10.1038/srep32881, 2016.

Jalali, B., Sicre, M.-A., Bassetti, M.-A., and Kallel, N.: Holocene climate variability in the North-Western Mediterranean Sea (Gulf of Lions), Clim. Past, 12, 91-101, https://doi.org/10.5194/cp-1291-2016, 2016.

Jiang, H., Muscheler, R., Björck, S., Seidenkrantz, M. S., Olsen, J., Sha, L., Sjolte, J., Eriksson, J., Ran, L., Knudsen, K. L., and Knudsen, M. F.: Solar forcing of Holocene summer sea-surface temperatures in the northern North Atlantic, Geology, 43, 203206, 2015.

Kissel, C., Van Toer, A., Laj, C., Cortijo, E., and Michel, E.: Variations in the strength of the North Atlantic bottom water during Holocene, Earth Planet. Sc. Lett., 369, 248-259, 2013.

Kobashi, T., Menviel, L., Jeltsch-Thömmes, A., Vinther, B. M., Box, J. E., Muscheler, R., Nakaegawa, T., Pfister, P. L., Döring, M., Leuenberger, M., Wanner, H., and Ohmura, A.: Volcanic influence on centennial to millennial Holocene Greenland temperature change, Nat. Sci. Rep., 7, 1441, https://doi.org/10.1038/s41598-017-01451-7, 2017.

Langehaug, H. R., Medhaug, I., Eldevik, T., and Otterå, O. H.: Arctic/Atlantic exchanges via the subpolar gyre, J. Climate, 25, 2421-2439, 2012.

Liu, F. and Feng, Z.: A dramatic climatic transition at $\sim 4000$ cal. yr $\mathrm{BP}$ and its cultural responses in Chinese cultural domains, Holocene, 22, 1181-1197, 2012.

Liu, Z., Yoshimura, K., Bowen, G. J., Buenning, N. H., Risi, C., Welker, J. M., and Yuan, F.: Paired oxygen isotope records reveal modern North American atmospheric dynamics during the Holocene, Nat. Commun., 5, 3701, https://doi.org/10.1038/ncomms4701, 2014.

Locarnini, R. A., Mishonov, A. V., Antonov, J. I., Boyer, T. P., Garcia, H. E., Baranova, O. K., Zweng, M. M., Paver, C. R., Reagan, J. R., Johnson, D. R., Hamilton, M., and Seidov, D.: World Ocean Atlas 2013, edited by: Levitus, S. and Mishonov, A., vol. 1: Temperature (Vol. 73, p. 40), MD: NOAA Atlas NESDIS, available at: http://www.nodc.noaa.gov/OC5/indprod.html (last access: 1 April 2019), 2013.

Luterbacher, J., Dietrich, D., Xoplaki, E., Grosjean, M., and Wanner, H.: European seasonal and annual temperature variability, trends, and extremes since 1500, Science, 30, 1499-1503, 2004.

Magny, M., Combourieu-Nebout, N., de Beaulieu, J. L., BoutRoumazeilles, V., Colombaroli, D., Desprat, S., Francke, A., Joannin, S., Ortu, E., Peyron, O., Revel, M., Sadori, L., Siani, G., Sicre, M. A., Samartin, S., Simonneau, A., Tinner, W., Vannière, B., Wagner, B., Zanchetta, G., Anselmetti, F., Brugiapaglia, E., Chapron, E., Debret, M., Desmet, M., Didier, J., Essallami, L., Galop, D., Gilli, A., Haas, J. N., Kallel, N., Millet, L., Stock, A., Turon, J. L., and Wirth, S.: North-south palaeohydrological contrasts in the central Mediterranean during the Holocene: tentative synthesis and working hypotheses, Clim. Past, 9, 2043 2071, https://doi.org/10.5194/cp-9-2043-2013, 2013.

Magri, D.: Late Quaternary vegetation history at Lagaccione near Lago di Bolsena (central Italy), Rev. Palaeobot. Palyno., 106, 171-208, 1999.

Magri, D. and Sadori, L.: Late Pleistocene and Holocene pollen stratigraphy at Lago di Vico, central Italy, Veg. Hist. Archaeobot., 8, 247-260, 1999.

Massé, G., Rowland, S., Sicre, M.-A., Jacob, J., Jansen, E., and Belt, S., Abrupt climate changes for Iceland during the last millennium: Evidence from high resolution sea ice reconstructions, Earth Planet. Sc. Lett., 269, 565-569, 2008. 
Mayewski, P. A., Rohling, E. E., Stager, J. C., Karlen, W., Maasch, K. A., Meeker, L. D., Meyerson, E. A., Gasse, F., van Kreveld, S., Holmgren, K., Lee-Thorp, J., Rosqvist, G., Rack, F., Staubwasser, M., Schneider, R. R., and Steig, E. J.: Holocene climate variability, Quaternary Res., 62, 243-255, 2004.

Mjell, T. L., Ninnemann, U. S., Eldevik, T., and Kleiven, H. K. F.: Holocene multidecadal-to millennial-scale variations in IcelandScotland overflow and their relationship to climate, Paleoceanography, 30, 558-569, 2015.

Moffa-Sánchez, P., Born, A., Hall, I. R., Thornalley, D. J., and Barker, S.: Solar forcing of North Atlantic surface temperature and salinity over the past millennium, Nat. Geosci., 7, 275, https://doi.org/10.1038/NGEO2094, 2014.

Moreno-Chamarro, E., Schmiedl, G., and Jungclaus, J. H.: Climate and ocean variability during the last millennium in paleoobservations and Earth system model simulations, Doctoral dissertation, Universität Hamburg, Hamburg, Germany, 2016.

Moreno-Chamarro, E., Zanchettin, D., Lohmann, K., Luterbacher, J., and Jungclaus, J. H.: Winter amplification of the European Little Ice Age cooling by the subpolar gyre, Sci. Rep., 7, 9981, https://doi.org/10.1038/s41598-017-07969-0, 2017.

Nakamura, A., Yokoyama, Y., Maemoku, H., Yagi, H., Okamura, M., Matsuoka, H., Miyake, N., Osada, T., Adhikari, D. P., and Dangol, V.: Weak monsoon event at 4.2 ka recorded in sediment from Lake Rara, Himalayas, Quatern. Int., 397, 349-359, 2016.

Ning, L., Liu, J., Bradley, R. S., and Yan, M.: Comparing the spatial patterns of climate change in the 9th and 5th millennia BP from TRACE-21 model simulations, Clim. Past, 15, 41-52, https://doi.org/10.5194/cp-15-41-2019, 2019.

O’Brien, S. R., Mayewski, P. A., Meeker, L. D., Meese, D., Twickler, M. S., and Whitlow, S. I.: Complexity of Holocene climate as reconstructed from a Greenland ice core, Science, 270, 19621964, 1995.

Prahl, F. G., Muehlhausen, L. A., and Zahnle, D. L.: Further evaluation of longchain alkenones as indicators of paleoceanographic conditions, Geochim. Cosmochim. Ac., 52, 2303-2310, 1988.

Quezel, P.: La région méditerranéenne française et ses essences forestières, signification écologique dans le contexte circumméditerranéen, Forêt Méd, 1, 7-18, 1979.

Ramsey, B. C.: Methods for Summarizing Radiocarbon Datasets, Radiocarbon, 59, 1809-1833, 2017.

Ran, L., Jiang, H., Knudsen, K. L., and Eiriksson, J.: A highresolution Holocene diatom record on the North Icelandic shelf, Boreas, 37, 399-413, 2008.

Reille, M.: Pollen et Spores d'Europe et d'Afrique du Nord, Laboratoire de Botanique historique et Palynologie, Marseille, France, 520 pp., 1992.

Reimer, P. J., Bard, E., Bayliss, A., Beck, J. W., Blackwell, P. G., Bronk Ramsey, C., Grootes, P. M., Guilderson, T. P., Haflidason, H., Hajdas, I., Hatt., C., Heaton, T. J., Homann, D. L., Hogg, A. G., Hughen, K. A., Kaiser, K. F., Kromer, B., Manning, S. W., Niu, M., Reimer, R. W., Richards, D. A., Scott, E. M., Southon, J. R., Staff, R. A., Turney, C. S. M., and van der Plicht, J.: IntCal13 and Marine13 radiocarbon age calibration curves $0-50,000$ years cal BP, Radiocarbon, 55, 1869-1887, 2013.

Ruan, J., Kherbouche, F., Genty, D., Blamart, D., Cheng, H., Dewilde, F., Hachi, S., Edwards, R. L., Régnier, E., and Michelot, J.-L.: Evidence of a prolonged drought ca. $4200 \mathrm{yr}$ BP correlated with prehistoric settlement abandonment from the Guel- daman GLD1 Cave, Northern Algeria, Clim. Past, 12, 1-14, https://doi.org/10.5194/cp-12-1-2016, 2016.

Sha, L., Jiang, H., Seidenkrantz M.-S., Muscheler R., Zhang, X., Knudsen M. F., Olsen J., Knudsen, K. L., and Zhang W.: Solar forcing as an important trigger for West Greenland sea-ice variability over the last mellennium, Quaternary Sci. Rev., 131, 148-156, 2016.

Sicre, M.-A., Yiou, P., Eiriksson, J., Ezat, U., Guimbaut, E., Dahhaoui, I., Knudsen, K.-L., Jansen, E., Turon, J.-L.: A 4500-year reconstruction of sea surface temperature variability at decadal time scales off North Iceland, Quaternary Sci. Rev. 27, 20412047, 2008.

Sicre, M. A., Jalali, B., Martrat, B., Schmidt, S., Bassetti, M. A., and Kallel, N.: Sea surface temperature variability in the North Western Mediterranean Sea (Gulf of Lion) during the Common Era, Earth Planet. Sc. Lett., 456, 124-133, 2016.

Solignac, S., de Vernal, A., and Hillaire-Marcel, C.: Holocene seasurface conditions in the North Atlantic - contrasted trends and regimes in the western and eastern sectors (Labrador Sea vs. Iceland Basin), Quaternary Sci. Rev., 23, 319-334, 2004.

Solignac, S., Giraudeau, J., and de Vernal, A.: Holocene sea surface conditions in the western North Atlantic: spatial and temporal heterogeneities, Paleoceanography, 21, PA2004, https://doi.org/10.1029/2005PA001175, 2006.

Stanley, J.-D., Krom, M. D., Cliff, R. A., and Woodward, J. C.: Nile flow failure at the end of the Old Kingdom, Egypt: Strontium isotopic and petrologic evidence, Geoarchaeology 18, 395-402, 2003.

Ternois, Y., Sicre, M.-A., Boireau, A., Conte, M. H., and Eglinton, G.: Evaluation of long-chain alkenones as paleo-temperature indicators in the Mediterranean Sea, Deep-Sea Res., 44, 271-286, 1997.

Thornalley, D. J., Elderfield, H., and McCave, I. N.: Holocene oscillations in temperature and salinity of the surface subpolar North Atlantic, Nature, 457, 7230, https://doi.org/10.1038/nature07717, 2009.

Walker, M. J., Berkelhammer, M., Björck, S., Cwynar, L. C., Fisher, D. A., Long, A. J., Lowe, J. J., Newnham, R. M., Rasmussen, S. O., and Weiss, H.: Formal subdivision of the Holocene Series/Epoch: a Discussion Paper by a Working Group of INTIMATE (Integration of ice-core, marine and terrestrial records) and the Subcommission on Quaternary Stratigraphy (International Commission on Stratigraphy), J. Quaternary Sci., 27, 649659, 2012.

Wanner, H., Solomina, O., Grosjean, M., Ritz, S. P., and Jetel, M.: Structure and origin of Holocene cold events, Quaternary Sci. Rev., 30, 3109-3123, 2011.

Wanner, H., Mercolli, L., Grosjean, M., and Ritz, S. P.: Holocene climate variability and change; a data-based review, J. Geol. Soc., 172, 254-263, 2014.

Weiss, H.: Megadrought, collapse, and resilience in late 3rd millennium BC Mesopotamia, in: 2200 BC - A climatic breakdown as a cause for collapse of the Wold World?, edited by: Meller, H., Arz, H. W., Jung, R., and Risch, R., Landesmuseum fur Vorgeschichte, Halle, Germany, 35-52, 2015.

Weiss, H.: Global megadrought, societal collapse and resilience at 4.2-3.9 ka BP across the Mediterranean and west Asia, PAGES Magazine, 24, 62-63, 2016. 
Weiss, H. and Bradley, R. S.: What drives societal collapse?, Science, 29, 609-610, 2001.

Yan, M. and Liu, J.: Physical processes of cooling and megadrought during the $4.2 \mathrm{kaBP}$ event: results from TraCE-21ka simulations, Clim. Past, 15, 265-277, https://doi.org/10.5194/cp15-265-2019, 2019.
Zanchetta, G., Regattieri, E., Isola, I., Drysdale, R. N., Bini, M., Baneschi, I., and Hellstrom, J. C.: The so-called " 4.2 event" in the central Mediterranean and its climatic teleconnections, Alp Mediterr. Quaternary, 29, 5-17, 2016. 